\title{
人工歯の咬合様式が咀嚼機能に及ぼす影響
}

\author{
城官寛史 \\ 九州歯科大学歯科補緅学第 1 講座（指導：豊田静夫＼cjkstart教授）
}

平成 2 年 5 月 1 日受理

\section{Effect of Occlusal System of Artificial Teeth on Masticatory Function Hirofumi Kido}

First Department of Prosthetic Dentistry (Director: Prof. Shizuo Toyoda) Kyushu Dental College, Kitakyushu, Japan

Various types of artificial teeth have been developed for the purpose of recovering masticatory ability in complete dentures. For denture wearers, it is very important for artificial teeth to have a high level of masticatory performance and also for the artificial teeth to harmonize with the denture wearers' masticatory function. The purpose of this study was to examine the effects of various artificial teeth and occlusion on masticatory function.

First, experimental dentures were made which could accomodate four types of artificial molars. These types of occlusion examined were full balanced occlusion (F. B.), lingualized occlusion (L. O.), non-balanced occlusion $\left(0^{\circ}\right)$ and modified 0 degree teeth with a metal cone at first molar to establish balanced occlusion (M. $0^{\circ}$ ). Next, masticatory performance of five subjects wearing these dentures was examined using artificial test food made of carnauba wax. Also, chewing rhythm and terminal masticatory area were examined during mastication of six kinds of food (boiled carrot, roast beef, fish cake, rice dumpling, sponge cake, and almond).

The results were as follows:

1) Characteristics of physical properties of the artificial test food were similar to almond with texturometer.

2 ) Average masticatory performance in wearing the experimental dentures was $1.68 \pm 0.77$ $\mathrm{kg} \cdot \mathrm{cm} / \mathrm{g}(\min .0 .88 \mathrm{~kg} \cdot \mathrm{cm} / \mathrm{g}, \max .4 .01 \mathrm{~kg} \cdot \mathrm{cm} / \mathrm{g})$.

3 ) Masticatory performance of $0^{\circ}$ type was higher than those of F. B. and L. O. types. M. $0^{\circ}$ type was on a similar level with $0^{\circ}$ type.

4) Chewing rhythm with $0^{\circ}$ type showed irregularity as compared to F. B. or L. O. types, and M. $0^{\circ}$ type was on a similar level with F. B. and L. Otypes.

5) Terminal masticatory area with M. $0^{\circ}$ type was smaller than other types with the exception of fish cake. Especially on chewing roast beef which has high cohesiveness, statistics showed the M. $0^{\circ}$ type's terminal masticatory area to be significantly smaller.

6 ) In Comparison of masticatory performance and terminal masticatory area, the subjects with high masticatory parformance showed a small terminal masticatory area. On the other 
hand, the subjects with low masticatory performance showed a large terminal masticatory area.
Key words : Complete denture/Artificial teeth/Masticatory performance/Chewing rhythm

\section{緒言}

総義㐘による機能回復を行うために種々の大きさ，形 態, 材質の人工歯が開発されている ${ }^{1-6)}$. 人工歯の種類 は咀嚼，発音，㴿堤の吸収，義歯の維持安定などに影響 を及ぼす因子であるため，人工歯の種類とこれらの事柄 との関わりについて多くの研究が行われてきた．特に咀 嚼機能の回復は総義歯補綴の主な目的であるので, 人工 歯の相違が咀嚼機能に及ぼす影響を調べる目的で，筋電 図, 咬合力および咀礵能率などの多方面から検討され, かなり詳細に報告されているで 関する研究において, 測定に使用した試験食品の性状を 客観的に明記した研究は少ない。また, 咀嚼能力と咀啷 運動リズムおょび咀嚼終末域を同時に検討した研究はな い.

そこで本研究では人工臼菻の咬合様式の相違が義歯装 着者の咀翾機能にどのような影響を及ぼすかを調べるた めに, 4 種の曰歯部人工歯が交換可能な義歯を作製し， あらかじめ性状を測定した人工試料を用いて咀骝能力を 測定した。 さらに，6種の食品を咀嚼させたときの咀嚼 運動経路を記録し, 咀嚼リズム, 咀嚼終末域を測定し た.これらの結果を検討したところいささかの知見を得 たので報告する.

\section{予備実験（研究方法および結果）}

本研究の目的は, 異なる 4 種の咬合様式を付与した義 歯について，人工試料を用いて明㘉能力を検討し，さら に, 実際に食品を咀嚼させたときの下顎運動の相違を比 較することである，そこで，まず予備実験として，人工 試料の性状, 咀嚼運動の比較実験に用いる食品の性状, および咀嚼運動記録に使用する記録装置の特性について 検討した.

\section{I ，人工試料抢よび食品の性状}

咀嚼能力の測定には佐藤 $(1958)^{16)}$ が開発した人工試 料を用いることにした，この人工試料は，カルナゥバ・ ワックス $50 \%$, 硫酸バリウム $50 \%$ から成り, 直径 5.0 $\mathrm{mm}$, 厚さ $3.0 \mathrm{~mm}$ の円柱状タブレットに成形されたも のである.
咀嘅運動路の比較に使用する食品は, ゆでた人参, 焼 肉, かまぼこくしだんご, カステラ, アーモンドの 6 種とした。これらは, 硬さ, 弾力性, 凝集性, 弾力性, 付着性により食品を分類した柳沢ら（1985） ${ }^{17)}$ の報告を 参考にして選択した。

人工試料を用いて測定した咀㘉能力と実際に食品を咀 䍛させたときの咀嚼運動路とを比較検討するためには, 人工試料がどの食品之類似しているかをあらかじめ調べ る必要がある。そこでテクスチュロメ一夕 GTX-2

(全研 KK 社製)（図 1) を用いて人工試料および各食 品の性状について検討した。

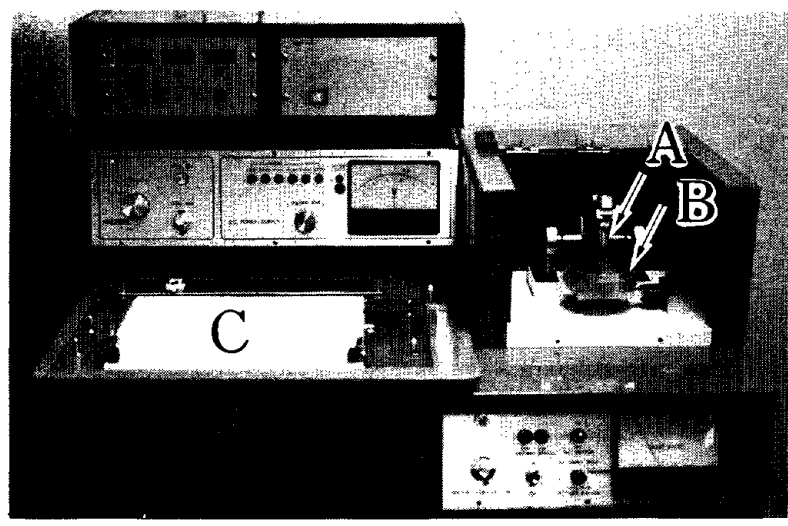

図1 テクスチュロメータ
$\mathrm{A}:$ プランジャ
$\mathrm{B}$ ：試料台
$\mathrm{C}$ : ペンレコーダ

テクスチュロメータは，2回の単純化した咀嚼運動で 試料を破壊し，そのときの応力を测定することによって 食品の硬さ, 弾力性, 凝集性, 付着性を定量する装置で ある(図2).

まず，人工試料および食品を規定の大きさに切断し， テクスチュロメータの試料台上に置いた。. 次に， 1 回咀 嚼/ 10 秒のスピードで直径 $13 \mathrm{~mm}$ のプランジャーを 下ろし，試料を破砕して，そのときの波形を付属のペン レコーダで記録した.

その測定結果を図 3 に示した。 人工試料は硬さのみが 大きかった。ゅでた人参は付着性がなく, 硬さ, 弾力 性, 凝集性が小さく, 焼肉は, 硬さ, 弾力性, 凝集性が 


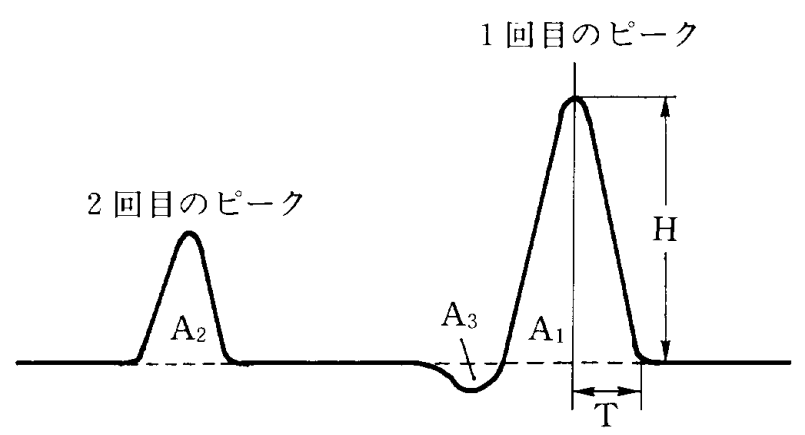

硬さ: $\mathrm{H}($ 目盛 $) /$ 入力電圧 $(\mathrm{kg})$ 凝集性： $\mathrm{A}_{2} / \mathrm{A}_{1}$ (面積比) 弾力性: $\mathrm{T}(\mathrm{mm})$

付着性: $A_{3} /$ 入力電然 $\left(\mathrm{cm}^{2}\right)$

図 2 テクスチュロメータの記録波形と測定項目

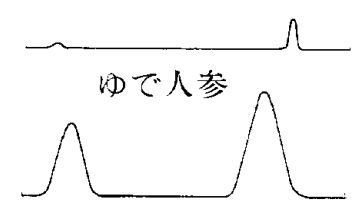

恅肉

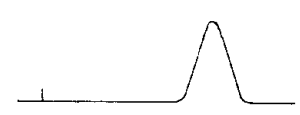

かまぼこ

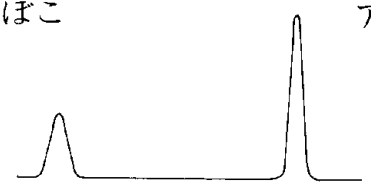

咀嚼能力試駘用人工試料

図 3 テクスチュロメータによる各食品の典型的 波形

大きかった．かまぼこは，テクスチュロメータによる1 回目の咀嚼で完全に切断されるため A 2 が現れないこ とが特徴であり, 硬さ, 弾力性が大きかった。くしだん ごは, 付着性があり, 硬さは小さく, 弾力性, 凝集性は 大きかった，カステラは, 硬さは小さいが弾力性, 凝集 性が大きく，アーモンドは，硬さのみが大きかった。

以上の测定結果より, 人工試料はアーモンドに類似し た性状であることがわかった。

II. 朋嚼運動の記録装置の特性

A. 自作プログラムにおける变換式の精度

本研究の目的の 1 つは，実際に食品を咀嚼させたとき の咀嚼開始から與下までの咀緭運動を記録し, 咀嚼リズ ム, 咀賈終末点のばらつきを調べることである.このた めには，下顎に付着した小型のマグネットの動きをセン
サーでとらえるマンディブラ・キネジオグラフ（K-6 DIAGNOSTIC SYSTEM マイオトロニクス社製, 以後 $\mathrm{MKG}$ と略す）が使用できると考えた。しかしながら MKG は，連続して 20 秒程度の記録しかできないため， 本実験に必要な此較的長時間の記録は不可能である。そ こでデータを $\mathrm{MKG} よ り$ 電圧の信号として取り出し, デ ジタル・レコーダを用いてサンプリング・レート 100 $\mathrm{Hz}$ で A / D 変換を行い, フロッピー・ディスクに記録 することにした。これにより咀嚼運動を長時間にわたっ て記録することが可能になった．フロッピー・ディスク に記録されたデータを解析するために自作のプログラム を開発した．このプログラムには前後方向，左右方向の 電圧のデータを距離に変換するため次の式を組み込ん だ.

前後方向距離 $(\mathrm{mm})=$ 電圧 $(\mathrm{mV}) / 100$

左右方向距離 $(\mathrm{mm})=$ 電圧 $(\mathrm{mV}) / 200$

そこで,この式から得られる電圧とマグネットの移動 によって变化する電圧の誤差を調べるために次の実験を 行った。

まず, 3 次元読取顕微鏡の微動部に長さ $50 \mathrm{~cm}$ のア クリル棒を装着し，その先端に MKGのマグネットを付 着した。 センサー・アレイとマグネットの位置関係を使 用説明に準じて決定し，センサー・アレイをアクリル製 の固定台に固定した，基点を自動調整機能によりディス プレイの中央に設定した後, マグネットを前後方向, 左 右方向へ $0.2 \mathrm{~mm}$ 間隔で最大 $3 \mathrm{~mm}$ まで移動させ, この ときの電圧の変化を MKGに接続した電圧計で読み取っ た。この電圧から算出した距離とマグネットの移動距離 との関係から, 誤差率 \{(出力電圧より算出した距離一 マグネットの移動距離）/マグネットの移動距離\}を求 めたところ最大䛊差率は, 前後方向では $4.0 \%$, 左右方 向では $6.3 \%$ であり，本研究に一分な精度であることが わかった。

\section{B. MKG の分解能}

咀嚼終末点を検討する場合には，終末点をできるだけ 細かく分離できることが望ましい．そこで本装置の分解 能を調べるために，前述の方法に準じてマグネットを $0.05 \mathrm{~mm}$ 間隔で移動させ, 移動距離と電圧の関係を調 ベたところ，この間隔では測定点は十分に分解でき，し かも良好な直線性が得られることがわかった。したがっ て, MKGは本研究に十分な分解能があると判断した。

\section{研究方法}

I 、被験者 
被験者は，九州歯科大学附属病院に義歯作製を希望し て来院した患者のうち，1）顎関節，粘膜に異常がな い, 2）上顎は無歯顎，下顎は $2 \sim 3$ 歯残存で OPA ア タッチメントを用いたオーバーデンチャーが適応でき る，3）義歯の予後が良好である，4）上下顎の対问関 係が正常である，5）実験に協力的である，の条件を満 たす男性 2 名，女性 3 名の計 5 名とした，各被験者の年 齢, 残存歯を表 1 に示す.

II. 実験用義歯の作製法および構造

A. 実験用義歯床の作製

臼歯部人工歯のみが交換可能な実験用義歯を次の方法 で作製した。

まず，上顎は総義歯，下顎は OPAアタッチメントを 用いたオーバーデンチャーを被験者に装着した。被験者 がこれらの義歯に十分慣れ，義歯が正常に機能している ことを確認したのち，西浦ら (1979) ${ }^{187}$ の方法に準じて 複製義㐘を作製した。この複製義歯を通法にしたがって

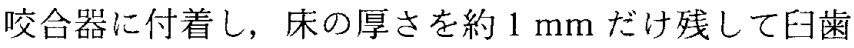
部を削除した。削除部に適合する厚さ約 $0.5 \mathrm{~mm}$ の金属 プレートを金銀パラジウム合金で作製して，削除部に接 着し，義歯体部を完成した，金属プレート上に即時重合 レジンで扫歯部人工歯を排列して人工印㐘部を作製し， 実験用義歯を完成した．義歯体部と人工臼歯部は分割可 能であり，両者を貫通するネジ穴が与えてあるのでスク リューによって固定できる（図 4 ）.

B. 人工田歯部に付与した咬合様式 使用した人工歯および咬合様式は以下の 4 種である.

1）上下顎にクロスマー20（ニッシン社製）を用い, 坪根ら (1984) ${ }^{19)}$ の方法に準じてフルバランスド・オク ルージョンを与えたもの，以下これを F. B. とする.

2）上顎にリブデント FB- 30 ( $\mathrm{G}-\mathrm{C}$ 社製)，下顎に クロスマー 20 を用い, Pound $(1971,1973)^{20.21)}$ の方

表 1 被験者の性別，年粭，残存歯

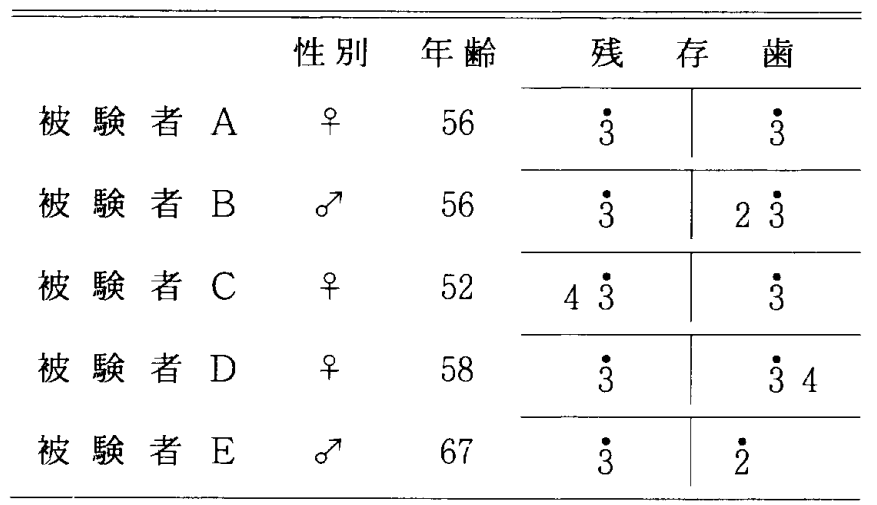

・ OPAアタッチメント適応歯

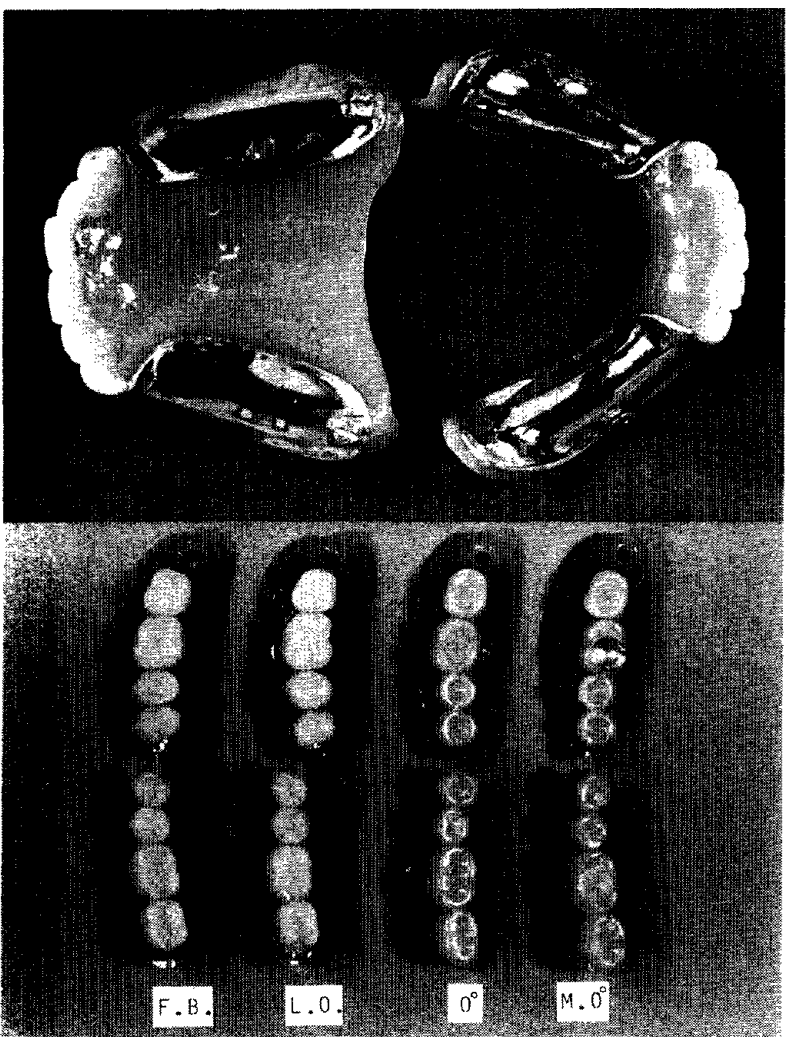

困 4 実験用義歯

法を参考にしてリンガライズド・オクルージョンを与え たあの．以下これをL.O. とする。

3）上下顎にゼロ日歯（松風社製）を排列し，バラン シング・ランプは付与しなかったもの，以下これを $0^{\circ}$ とする。

4）上下顎にゼロ臼歯（松風社製）を排列し，この上 顎第一大歯の近心舌側咬頭部に $20^{\circ}$ の傾斜をもつ金属 製機能突起を与え，下顎第一大臼歯のそれに適合する部 にレジン製の窩を与えたもの，以下これをM. $0^{\circ}$ とす る.

この実験用義歯を，1力月間被験者に使用させた。こ の間，必要に応じて調整を加え，実験用義歯が不都合な く機能することを確認した後，巨歯部人工歯を交換し， 1 週間後に来院させ, 咀嚼能力試験, 咀嚼運動記録を 行った，咀䍛運動記録に使用した食品の順序はアトラン ダムとした，実験終了後，臼歯部人工歯を他のタイプの 咬合様式に交換して 1 週間使用させ，同様の実験を行っ た.これを繰り返して，1人の被験者に対して 4 種の咬 合様式の義歯を使用した場合の咀嚼能力試験, 咀嚼運動 記録を行った。

III. 咀嚼能力について

A. 测定方法

咀嚼能力の測定には佐藤 $(1958)^{16)}$ が開発した人工試 
表 2 粉砕された人工試料の篩上重量\%

\begin{tabular}{|c|c|c|c|c|c|c|}
\hline & 咬合様式 & 8 mesh & $14 \mathrm{mesh}$ & $28 \mathrm{mesh}$ & $48 \mathrm{mesh}$ & 100 mesh \\
\hline \multirow{4}{*}{ 被鈳者 A } & F.B. & 96.02 & 97.61 & 98.02 & 98.40 & 98.47 \\
\hline & L.O. & 98.74 & 99.30 & 99.34 & 99.36 & 99.38 \\
\hline & $0^{\circ}$ & 89.40 & 94.24 & 95.88 & 96.36 & 96.58 \\
\hline & M. $0^{\circ}$ & 92.55 & 96.14 & 97.42 & 98.05 & 98.17 \\
\hline \multirow{4}{*}{ 被 験者 B } & F.B. & 85.88 & 95.19 & 97.38 & 98.39 & 98.73 \\
\hline & L.O. & 83.90 & 93.00 & 96.45 & 98.10 & 98.75 \\
\hline & $0^{\circ}$ & 59.69 & 83.26 & 92.04 & 96.08 & 97.92 \\
\hline & M. $0^{\circ}$ & 70.60 & 86.41 & 93.89 & 96.57 & 98.13 \\
\hline \multirow{4}{*}{ 被 験者 C } & F.B. & 91.58 & 97.19 & 98.42 & 98.91 & 98.97 \\
\hline & L.O. & 95.78 & 98.28 & 99.09 & 99.35 & 99.39 \\
\hline & $0^{\circ}$ & 84.50 & 94.42 & 96.52 & 97.24 & 97.64 \\
\hline & M. $0^{\circ}$ & 90.62 & 95.00 & 97.17 & 98.19 & 98.45 \\
\hline \multirow{4}{*}{ 被験者 D } & F.B. & 96.67 & 98.63. & 99.17 & 99.39 & 99.47 \\
\hline & L.O. & 92.84 & 97.62 & 98.84 & 99.26 & 99.30 \\
\hline & $0^{\circ}$ & 93.98 & 97.55 & 98.75 & 99.25 & 99.33 \\
\hline & M. $0^{\circ}$ & 89.44 & 95.31 & 97.63 & 98.65 & 98.91 \\
\hline \multirow{4}{*}{ 被 験者 $\mathrm{E}$} & F.B. & 98.13 & 98.77 & 99.01 & 99.24 & 99.32 \\
\hline & L.O. & 98.53 & 99.22 & 99.38 & 99.48 & 99.50 \\
\hline & $0^{\circ}$ & 95.42 & 97.39 & 98.25 & 98.85 & 99.00 \\
\hline & M. $0^{\circ}$ & 93.00 & 97.00 & 98.03 & 98.41 & 98.61 \\
\hline
\end{tabular}

料を用いて，鱒見（1984） ${ }^{22 !}$ の方法に従って咀嚼能力を 測定した。すなわち，被験者の口腔内をよく清掃し，あ らかじめ科量した人工試料約 $5 \mathrm{~g}$ (整数倜) を 1 秒に 1 回のペースで 10 回咀嚼させた。㕨喘後の人工試料を回 収し，8，14，28，48，100 mesh の順に重敉た Tyler の笠を用いて篩い分けを行い, 乾燥後, 各篩の粉砕試料 を秤量した。

\section{B. 検定方法}

粉砕された人工試料の各篩每の篩上重量\%を表 2 に示 した。 それぞれの試料で 8，14，28，48，100 meshの 篩上重量\%による粘度分布が Rosin-Rammlar の実験 式を満足することを確認した後, 8 mesh 篩上量を用い て哟嚼能力を求めた。咀嚼能力は, 8 mesh 篩上.量を太 田 $(1966)^{23,}$ の式 $\left\{\mathrm{Y}=-4.98 \times 10^{-4} \mathrm{X}^{2}-0.130 \times\right.$ $10^{2} \mathrm{X}+5.86 \quad \mathrm{X}$ : 8 mesh 篩上量（重量\%） $\mathrm{Y}$ : 咀嚼 能力 $(\mathrm{kg} \cdot \mathrm{cm} / \mathrm{g})\}$ に代入し, エネルギーであらわし た。

\section{IV. 朋嚼運動の記録}

\section{A. 実験装置}

本実験では咀嚼開始から燕下までの比較的長時間の記 録が必要であるので，データをデジタル・レコーダを用
いてフロッピー・ディスクに記録し，16ビット・パー ソナル・コンピューター（NEC PC-9801 VM 2) 上. で自作のプログラムを用いて解析した。

B．実験に用いた食品

実験に用いる食品は数種の異なる性状のむのが望まし い、そこで,ゆでた人参, 焼肉, かまぼこ，くしだん ご，カステラ，アーモンドの 6 種の食品について勗嚼運 動の記録を行った。 1 度に咀嚼させる量は,アーモンド は 1 粒, 他の食品は 1 辺が $1 \mathrm{~cm}$ の立方体を 3 個とし た。

C. 記録方法

実験用義歯の下顎中切菌㐘頸部に MKG のマグネット をバリケア（マイオトロニクス社製）を用いて付着し た。実験用義㐘を被験者の口空内に装着し, 通法に従い MKGのセンサー・アレイを装着, 調整した。, 食品を舌 上に置きここれを咬まないように指示して咬頭嵌合位を 上らせ，咬頭㰠合位を数秒間記録した後，䁵下までの咀 嚼運動を記録した。咀嚼側は習慣性咀嚼側とし，記録中 は, 被験者の頭部を木製の鞍頭台で可及的に固定し だ.

D. 测定項月 


\section{1. 嚼リズムについて}

咬合様式の違いが咀嚼リズムに与える影響を調べるた めに咀嚼周期の所要時間を測定した。まず，晈頭嵌合位 に比較的近い位置において運動方向が上方から下方に変 化する点で咀嚼運動記録を個々の咀嚼周期に分解した。 全ての咀嚼周期のうち咀嚼開始直後と嬹下直前を除く最 屯安定した連続 10 回の咀嚼周期を選択して個々の咀嚼 周期に要した時間を測定し，その平均值と標準偏差から 変動係数を求めた.

\section{2. 咀嚼終末域について}

咀嚼終末点のばらつきの程度を調べるために，和久田 $(1984)^{25 j}$ のタッピング・エリア測定法に準じて咀嚼終 末域を求めた。すなわち, 食品咀嚼時の咀嚼運動記録上 $り$ ，最它安定した連続 10 回の咀嚼周期を選択して，咀 嚼終末点の水平面に扮ける座標を求めた。この座標の左 右方向におけるばらつきの指標である標準偏差 amm と 前後方向におけるばらつきの指標である標準偏差 bmm を古とに，2 $\mathrm{a} \times 2 \mathrm{bmm}^{2}$ を求め，咀嚼終末域とした (网 5 ).

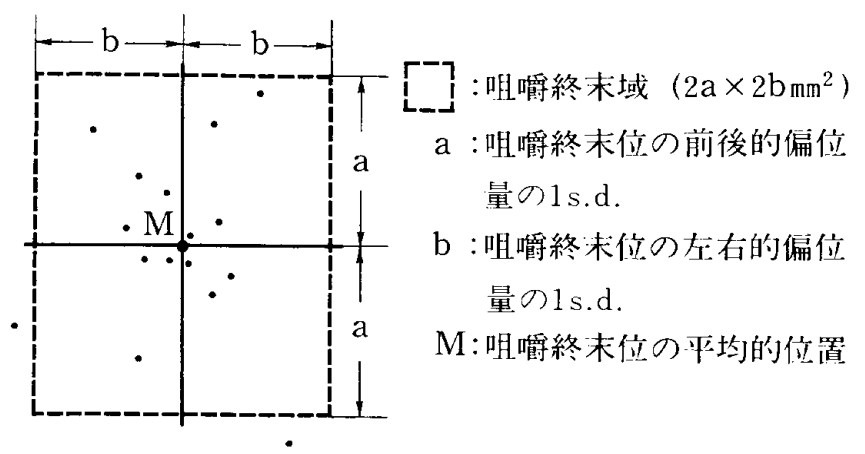

网 5 咀嚼終末域の模式図

\section{結果}

I 。咀嚼能力について

5 名の被験者の各咬合様式における咀嚼能力の結果を 表 3 に示した。

1 名を除いた全ての被験者において F. B.，L.O.よ りも $0^{\circ}$, M. $0^{\circ}$ の方が高い勗嚼能力であった。各咬合 様式で 5 名の被験者の咀嚼能力の平均值を求めたとこ 乃，咀嚼能力が最も高かったのは $0^{\circ} の 2.09 \pm 1.02$ $\mathrm{kg} \cdot \mathrm{cm} / \mathrm{g}$, ついでM. $0^{\circ} の 1.92 \pm 0.70 \mathrm{~kg} \cdot \mathrm{cm} / \mathrm{g}$, F. B. $の 1.36 \pm 0.42 \mathrm{~kg} \cdot \mathrm{cm} / \mathrm{g}, \quad$ L. O. $の 1.33 \pm 0.50$ $\mathrm{kg} \cdot \mathrm{cm} / \mathrm{g}$ の順であった。咬合様式間で平均值の差の 検定を行ったところ，M. $0^{\circ}$ は F. B.， L. O. より有意 に咀嚼能力が高かった。 また， $0^{\circ}$ は，F. B., L. O.上 り咀嚼能力が高い傾向があった. $0^{\circ}$ と M. $0^{\circ}$ の間には
有意差は認められなかった。

II. 咀嚼リズムについて

咀嚼リズムの規則性を比較するために 10 回の咀嚼周 期の所要時間の平均值および標準偏差から变動係数を算 出した。

ゆでた人参咀嚼時における咀嚼周期の所要時間の平均 は $0.689 \pm 0.092 \mathrm{sec}$ であった. 変動係数の平均は, F. B. : $0.115 \pm 0.032$, L. O. : $0.099 \pm 0.031,0^{\circ}:$ $0.154 \pm 0.035, \quad$ M. $0^{\circ}: 0.107 \pm 0.045$ であり, $0^{\circ}$ の変

表 3 咀嚼能力

\begin{tabular}{c|cccc}
\hline \hline & F.B. & L.O. & $0^{\circ}$ & $\mathrm{M.0}$ \\
\hline 被 験者 A & 1.14 & 0.88 & 1.76 & 1.47 \\
被 験 者 B & 2.08 & 2.25 & 4.01 & 3.29 \\
被 験 者 C & 1.56 & 1.17 & 2.14 & 1.65 \\
被 験 者 D & 1.08 & 1.45 & 1.34 & 1.76 \\
被 験者 E & 0.94 & 0.90 & 1.20 & 1.43 \\
\hline 平 均 & 1.36 & 1.33 & 2.09 & 1.92 \\
S.D. & 0.42 & 0.50 & 1.02 & 0.70 \\
\hline
\end{tabular}

$(\mathrm{kg} \cdot \mathrm{cm} / \mathrm{g})$

表 4 咀嚼リズム（ゆでた人参）

\begin{tabular}{|c|c|c|c|c|c|}
\hline & & F.B. & L. O. & $0^{\circ}$ & M. $0^{\circ}$ \\
\hline \multirow{3}{*}{ 被験者 A } & $\overline{\mathrm{X}}$ & 0.620 & 0.660 & 0.640 & 0.590 \\
\hline & s.d. & 0.058 & 0.054 & 0.113 & 0.053 \\
\hline & C. V. & 0.094 & 0.082 & 0.177 & 0.090 \\
\hline \multirow{3}{*}{ 被験者B } & $\bar{X}$ & 0.670 & 0.600 & 0.630 & 0.590 \\
\hline & s.d. & 0.103 & 0.061 & 0.094 & 0.084 \\
\hline & C. V. & 0.154 & 0.102 & 0.149 & 0.142 \\
\hline \multirow{3}{*}{ 被験者 C } & $\bar{X}$ & 0.590 & 0.630 & 0.680 & 0.710 \\
\hline & s.d. & 0.063 & 0.060 & 0.129 & 0.081 \\
\hline & C. V. & 0.107 & 0.095 & 0.190 & 0.114 \\
\hline \multirow{3}{*}{ 被験者D } & $\bar{X}$ & 0.870 & 0.590 & 0.870 & 0.800 \\
\hline & s.d. & 0.129 & 0.092 & 0.144 & 0.127 \\
\hline & C.V. & 0.148 & 0.156 & 0.166 & 0.159 \\
\hline \multirow{5}{*}{ 被験者 $\mathrm{E}$} & $\bar{X}$ & 0.710 & 0.780 & 0.830 & 0.710 \\
\hline & s.d. & 0.050 & 0.048 & 0.075 & 0.022 \\
\hline & C.V. & 0.070 & 0.062 & 0.090 & 0.031 \\
\hline & $\overline{\mathrm{C} . \mathrm{V}}$. & 0.115 & 0.099 & 0.154 & 0.107 \\
\hline & s.d. & 0.032 & 0.031 & 0.035 & 0.045 \\
\hline
\end{tabular}


表 5 咀嚼リズム（焼肉）

\begin{tabular}{|c|c|c|c|c|c|}
\hline & & F.B. & L.O. & $0^{\circ}$ & M. $0^{\circ}$ \\
\hline \multirow{3}{*}{ 被験者A } & $\bar{X}$ & 0.610 & 0.650 & 0.640 & 0.630 \\
\hline & s.d. & 0.044 & 0.031 & 0.060 & 0.030 \\
\hline & C.V. & 0.072 & 0.048 & 0.094 & 0.048 \\
\hline \multirow{3}{*}{ 被験者B } & $\bar{X}$ & 0.590 & 0.650 & 0.640 & 0.640 \\
\hline & s.d. & 0.065 & 0.060 & 0.104 & 0.078 \\
\hline & C.V. & 0.110 & 0.092 & 0.163 & 0.122 \\
\hline \multirow{3}{*}{ 被験者C } & $\bar{X}$ & 0.730 & 0.700 & 0.760 & 0.880 \\
\hline & s.d. & 0.076 & 0.089 & 0.115 & 0.066 \\
\hline & C.V. & 0.104 & 0.127 & 0.151 & 0.075 \\
\hline \multirow{3}{*}{ 被験者D } & $X$ & 0.830 & 0.750 & 0.890 & 0.720 \\
\hline & s.d. & 0.091 & 0.056 & 0.112 & 0.062 \\
\hline & C.V. & 0.110 & 0.075 & 0.126 & 0.086 \\
\hline \multirow{5}{*}{ 被験者 E } & $\bar{X}$ & 0.810 & 0.800 & 0.680 & 0.710 \\
\hline & s.d. & 0.070 & 0.058 & 0.049 & 0.050 \\
\hline & C.V. & 0.086 & 0.073 & 0.072 & 0.070 \\
\hline & $\overline{C . V}$. & 0.096 & 0.083 & 0.121 & 0.080 \\
\hline & s.d. & 0.015 & 0.026 & 0.034 & 0.024 \\
\hline
\end{tabular}

*危険率 $5 \%$ で有意

$(\mathrm{sec})$

動係数は，L. O, M. $0^{\circ}$ より有意に大きかった．また，

M. $0^{\circ}$ は F. B., L. O.とほぼ同程度の変動係数であった (表 4).

焼肉咀嚼時にお污る咀嚼周期の所要時間の平均は $0.716 \pm 0.087 \mathrm{sec}$ であった。変動係数の平均は，F. B. : $0.096 \pm 0.015, \quad$ L. O. $: 0.083 \pm 0.026,0^{\circ}:$ $0.121 \pm 0.034$, M. $0^{\circ}: 0.080 \pm 0.024$ であった. $0^{\circ}$ の 変動係数は L. O., M. $0^{\circ}$ と比較して有意に大きく, M. $0^{\circ}$ は F. B., L. O. と同程度の变動係数であった（表 $5)$.

かまぼこ咀嚼時における咀緭周期の所要時間の平均は $0.667 \pm 0.078 \mathrm{sec}$ であった。変動係数の平均は, F. B. : $0.088 \pm 0.027$, L. O. $: 0.109 \pm 0.037,0^{\circ}$ : $0.125 \pm 0.036$, M. $0^{\circ}: 0.073 \pm 0.025$ であった. $0^{\circ}$ の 変動係数が最も大きく, M. $0^{\circ}$ の変動係数は L. 0. , $0^{\circ}$ 之比較して有意に小さかった（表 6 ).

くしだんご咀嚼時における咀嚼周期の所要時間の平均 は $0.739 \pm 0.095 \mathrm{sec}$ であった. 変動係数の平均は, F. B. : $0.108 \pm 0.041$, L. O. : $0.125 \pm 0.056,0^{\circ}$ : $0.094 \pm 0.024$, M. $0^{\circ}: 0.116 \pm 0.045$ であり, 咬合様式 間での差は認められなかった（表 7 ).
表 6 咀嚼リズム（かまぼこ）

\begin{tabular}{|c|c|c|c|c|c|}
\hline & & F.B. & L.O. & $0^{\circ}$ & M. $0^{\circ}$ \\
\hline \multirow{3}{*}{ 被験者 A } & $\mathrm{X}$ & 0.630 & 0.590 & 0.580 & 0.590 \\
\hline & s.d. & 0.024 & 0.056 & 0.047 & 0.030 \\
\hline & C.V. & 0.038 & 0.095 & 0.081 & 0.051 \\
\hline \multirow{3}{*}{ 被験者B } & $\bar{X}$ & 0.570 & 0.580 & 0.620 & 0.620 \\
\hline & s.d. & 0.063 & 0.086 & 0.099 & 0.069 \\
\hline & C.V. & 0.111 & 0.148 & 0.160 & 0.111 \\
\hline \multirow{3}{*}{ 被験者 C } & $\bar{X}$ & 0.620 & 0.610 & 0.760 & 0.690 \\
\hline & s.d. & 0.064 & 0.042 & 0.096 & 0.040 \\
\hline & C.V. & 0.103 & 0.069 & 0.126 & 0.058 \\
\hline \multirow{3}{*}{ 被験者D } & $X$ & 0.690 & 0.620 & 0.810 & 0.720 \\
\hline & s.d. & 0.057 & 0.098 & 0.138 & 0.068 \\
\hline & C.V. & 0.083 & 0.158 & 0.170 & 0.094 \\
\hline \multirow{5}{*}{ 被験者 E } & $\bar{X}$ & 0.760 & 0.820 & 0.750 & 0.700 \\
\hline & s.d. & 0.081 & 0.061 & 0.066 & 0.035 \\
\hline & C.V. & 0.107 & 0.074 & 0.088 & 0.050 \\
\hline & C.V. & 0.088 & 0.109 & 0.125 & 0.073 \\
\hline & s.d. & 0.027 & 0.037 & 0.036 & 0.025 \\
\hline
\end{tabular}

表 7 咀嚼リズム（くしだんご）

\begin{tabular}{|c|c|c|c|c|c|}
\hline & & F.B. & L.O. & $0^{\circ}$ & M. $0^{\circ}$ \\
\hline \multirow{3}{*}{ 被験者A } & $\bar{X}$ & 0.780 & 0.720 & 0.730 & 0.670 \\
\hline & s.d. & 0.050 & 0.050 & 0.058 & 0.069 \\
\hline & C.V. & 0.064 & 0.069 & 0.079 & 0.103 \\
\hline \multirow{3}{*}{ 被験者 B } & $\bar{X}$ & 0.580 & 0.600 & 0.600 & 0.620 \\
\hline & s.d. & 0.075 & 0.040 & 0.056 & 0.085 \\
\hline & C.V. & 0.129 & 0.067 & 0.093 & 0.137 \\
\hline \multirow{3}{*}{ 被験者 C } & $\bar{X}$ & 0.710 & 0.750 & 0.740 & 0.770 \\
\hline & s.d. & 0.057 & 0.093 & 0.067 & 0.144 \\
\hline & C.V. & 0.080 & 0.124 & 0.191 & 0.187 \\
\hline \multirow{3}{*}{ 被験者 D } & $\overline{\mathrm{X}}$ & 0.870 & 0.810 & 0.940 & 0.910 \\
\hline & s.d. & 0.154 & 0.177 & 0.131 & 0.094 \\
\hline & C.V. & 0.177 & 0.219 & 0.139 & 0.103 \\
\hline \multirow{5}{*}{ 被験者 $\mathrm{E}$} & $\bar{X}$ & 0.760 & 0.770 & 0.730 & 0.710 \\
\hline & s.d. & 0.067 & 0.112 & 0.050 & 0.035 \\
\hline & C.V. & 0.088 & 0.145 & 0.068 & 0.049 \\
\hline & $\overline{\mathrm{C} . \mathrm{V}}$. & 0.108 & 0.125 & 0.094 & 0.116 \\
\hline & s.d. & 0.041 & 0.056 & 0.024 & 0.045 \\
\hline
\end{tabular}


表 8 咀嚼りズム（カステラ）

\begin{tabular}{|c|c|c|c|c|c|}
\hline & & F.B. & L.O. & $0^{\circ}$ & M. $0^{\circ}$ \\
\hline \multirow{3}{*}{ 被験者A } & $\mathrm{X}$ & 0.700 & 0.670 & 0.730 & 0.680 \\
\hline & s.d. & 0.062 & 0.053 & 0.073 & 0.084 \\
\hline & C.V. & 0.089 & 0.079 & 0.100 & 0.124 \\
\hline \multirow{3}{*}{ 被験者B } & $X$ & 0.610 & 0.620 & 0.610 & 0.630 \\
\hline & s.d. & 0.114 & 0.045 & 0.056 & 0.126 \\
\hline & C.V. & 0.187 & 0.073 & 0.092 & 0.200 \\
\hline \multirow{3}{*}{ 被験者 C } & $\bar{X}$ & 0.590 & 0.810 & 0.830 & 0.790 \\
\hline & s.d. & 0.060 & 0.128 & 0.125 & 0.138 \\
\hline & C.V. & 0.102 & 0.158 & 0.151 & 0.175 \\
\hline \multirow{3}{*}{ 被験者D } & $\bar{X}$ & 0.940 & 0.660 & 0.740 & 0.800 \\
\hline & s.d. & 0.072 & 0.063 & 0.091 & 0.095 \\
\hline & C.V. & 0.077 & 0.095 & 0.123 & 0.119 \\
\hline \multirow{5}{*}{ 被験者 E } & X & 0.780 & 0.790 & 0.740 & 0.730 \\
\hline & s.d. & 0.059 & 0.060 & 0.035 & 0.037 \\
\hline & C.V. & 0.076 & 0.076 & 0.047 & 0.051 \\
\hline & C.V. & 0.106 & 0.096 & 0.103 & 0.134 \\
\hline & s.d. & 0.042 & 0.032 & 0.034 & 0.052 \\
\hline
\end{tabular}

表 9 咀嚼リズム（アーモンド）

\begin{tabular}{l|c|cccc}
\hline \hline & & F.B. & L.O. & $0^{\circ}$ & M. $0^{\circ}$ \\
\hline \multirow{4}{*}{ 被験者A } & $\overline{\mathrm{X}}$ & 0.650 & 0.600 & 0.530 & 0.640 \\
& $\mathrm{~s} . \mathrm{d}$. & 0.040 & 0.054 & 0.074 & 0.058 \\
& $\mathrm{C} . \mathrm{V}$. & 0.062 & 0.090 & 0.140 & 0.091 \\
\hline & $\overline{\mathrm{X}}$ & 0.540 & 0.590 & 0.570 & 0.560 \\
被験者B & $\mathrm{s} . \mathrm{d}$. & 0.051 & 0.069 & 0.092 & 0.062 \\
& $\mathrm{C} . \mathrm{V}$. & 0.094 & 0.117 & 0.161 & 0.111 \\
\hline & $\overline{\mathrm{X}}$ & 0.880 & 0.740 & 0.580 & 0.790 \\
被験者C & $\mathrm{s} . \mathrm{d}$. & 0.056 & 0.070 & 0.049 & 0.087 \\
& $\mathrm{C} . \mathrm{V}$. & 0.064 & 0.095 & 0.084 & 0.110 \\
\hline \multirow{5}{*}{ 被験者D } & $\overline{\mathrm{X}}$ & 0.710 & 0.630 & 0.670 & 0.720 \\
& $\mathrm{~s} . \mathrm{d}$. & 0.073 & 0.068 & 0.095 & 0.064 \\
& $\mathrm{C} . \mathrm{V}$. & 0.103 & 0.108 & 0.142 & 0.089 \\
\hline & $\overline{\mathrm{X}}$ & 0.780 & 0.680 & 0.630 & 0.640 \\
被験者E & $\mathrm{s} . \mathrm{d}$. & 0.083 & 0.060 & 0.044 & 0.041 \\
& $\mathrm{C} . \mathrm{V}$. & 0.106 & 0.088 & 0.070 & 0.064 \\
\hline & $\overline{\mathrm{C} . \mathrm{V} .}$ & 0.086 & 0.100 & 0.119 & 0.093 \\
& $\mathrm{~s} . \mathrm{d}$. & 0.019 & 0.011 & 0.036 & 0.017 \\
\hline
\end{tabular}

表10 咀嚼終末域（ゆでた人参）

\begin{tabular}{c|cccc}
\hline \hline & F.B. & L.O. & $0^{\circ}$ & M. $0^{\circ}$ \\
\hline 被 験者 A & 0.43 & 0.27 & 0.83 & 0.33 \\
被 験者 B & 0.02 & 0.04 & 0.03 & 0.03 \\
被 験者 C & 0.03 & 0.07 & 0.18 & 0.15 \\
被 験者 D & 0.43 & 0.31 & 1.00 & 0.59 \\
被 験 者 E & 0.25 & 0.68 & 0.17 & 0.21 \\
\hline $\bar{X}$ & 0.23 & 0.27 & 0.44 & 0.26 \\
s.d. & 0.18 & 0.23 & 0.39 & 0.19 \\
\hline
\end{tabular}

表11 咀嚼終末域（焼肉）

\begin{tabular}{|c|c|c|c|c|}
\hline & F.B. & L.O. & $0^{\circ}$ & M. $0^{\circ}$ \\
\hline 被験者 A & 0.44 & 0.18 & 0.59 & 0.22 \\
\hline 被験者 B & 0.07 & 0.04 & 0.03 & 0.08 \\
\hline 被験者 C & 0.61 & 0.04 & 0.11 & 0.10 \\
\hline 被験者 D & 0.50 & 0.38 & 1.11 & 0.30 \\
\hline 被験者 E & 0.79 & 1.14 & 0.54 & 0.30 \\
\hline$\overline{\mathrm{X}}$ & 0.48 & 0.36 & 0.48 & 0.20 \\
\hline s.d. & 0.24 & 0.41 & 0.39 & 0.09 \\
\hline
\end{tabular}

カステラ咀嚼時における咀嚼周期の所要時間の平均は $0.723 \pm 0.088 \mathrm{sec}$ であった。変動係数の平均は, F. B. : $0.106 \pm 0.042$, L. O. $: 0.096 \pm 0.032, \quad 0^{\circ}: 0.103$ $\pm 0.034, \quad$ M. $0{ }^{\circ} 0.134 \pm 0.052$ であり, 咬合様式間での 差は認められなかった（表 8 ）。

アーモンド咀罚時における咀嚼周期の所要時間の平均 は $0.657 \pm 0.089 \mathrm{sec}$ であった，変動係数の平均は，F． B. : $0.086 \pm 0.019$, L. O. $: 0.100 \pm 0.011,0^{\circ}: 0.119$ \pm 0.036, M. $0^{\circ}: 0.093 \pm 0.017$ であった. $0^{\circ}$ の変動 係数が最む大きい值であったが, 咬合様式間での有意差 は認められなかった（表 9).

全食品を通じて M. $0^{\circ}$ の変動係数は 0 に比較して小 さい傾向であり，F.B., L.O. とは有意差はなかった。

III. 咀嚼終末域について

6 種の食品を咀嚼させたときの咀嘅終末点のばらつき の程度を咀嚼終末域として算出した。

ゆでた人参咀嚼時の咀嚼終末域の平均は，F. B. : $0.23 \pm 0.18 \mathrm{~mm}^{2}$, L. O. $: 0.27 \pm 0.23 \mathrm{~mm}^{2}, 0^{\circ}: 0.44$ $\pm 0.39 \mathrm{~mm}^{2}, \quad$ M. $0^{\circ}: 0.26 \pm 0.19 \mathrm{~mm}^{2}$ であり, $0^{\circ}$ の 平均咀嚼終末域が他の咬合様式より大きく, M. $0^{\circ}$ は 
F. B. , L. O. と同程度の咀嚼終末域であったが，統計 的有意差はなかった（表 10）。

焼肉咀嚼時では, F. B. : $0.48 \pm 0.24 \mathrm{~mm}^{2}, \quad$ L. O. : $0.36 \pm 0.41 \mathrm{~mm}^{2}, \quad 0^{\circ}: 0.48 \pm 0.39 \mathrm{~mm}^{2}, \quad$ M. $0^{\circ}: 0.20 \pm 0.09 \mathrm{~mm}^{2}$ であり, $0^{\circ}$ はF. B., L. O. と

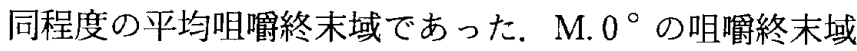
は L. O., $0^{\circ} よ り$ 小さい傾向であり，F. B. と比較し て有意に小さかった（表 11）。

かまぼこ咀嚼時では, F. B. $: 0.10 \pm 0.06 \mathrm{~mm}^{2}$, L. $\mathrm{O}: 0.19 \pm 0.22 \mathrm{~mm}^{2}, \quad 0^{\circ}: 0.27 \pm 0.18 \mathrm{~mm}^{2}$, M. $0^{\circ}$ : $0.27 \pm 0.20 \mathrm{~mm}^{2}$ であり, F. B. の平均咀嚼終末域は他 の咬合様式より小さかったが統計的に有意ではなかった (表 12).

くしだんご咀嚼時では，F. B. : $0.31 \pm 0.22 \mathrm{~mm}^{2}$, L. O. $: 0.23 \pm 0.15 \mathrm{~mm}^{2}, \quad 0^{\circ}: 0.28 \pm 0.24 \mathrm{~mm}^{2}, \quad$ M. $0^{\circ}: 0.20 \pm 0.14 \mathrm{~mm}^{2}$ であり, 咬合様式間で有意差は 認められなかった（表 13）.

カステラ咀嚼時では, F. B. : $0.11 \pm 0.09 \mathrm{~mm}^{2}, \quad$ L. O. : $0.15 \pm 0.11 \mathrm{~mm}^{2}, \quad 0^{\circ}: 0.16 \pm 0.09 \mathrm{~mm}^{2}, \quad$ M. $0^{\circ}: 0.10 \pm 0.07 \mathrm{~mm}^{2}$ であり, 他の食品と比較して全

表12 咀罟終末域（かまぼこ）

\begin{tabular}{c|cccc}
\hline \hline & F.B. & L.O. & $0^{\circ}$ & M. $0^{\circ}$ \\
\hline 被験者 A & 0.18 & 0.08 & 0.10 & 0.12 \\
被験者 B & 0.02 & 0.03 & 0.02 & 0.06 \\
被験 者 C & 0.03 & 0.02 & 0.34 & 0.62 \\
被験 者 D & 0.12 & 0.21 & 0.38 & 0.23 \\
被験 者 E & 0.15 & 0.62 & 0.50 & 0.31 \\
\hline $\bar{X}$ & 0.10 & 0.19 & 0.27 & 0.27 \\
S.d. & 0.06 & 0.22 & 0.18 & 0.20 \\
\hline
\end{tabular}

( $\left.\mathrm{m}^{2}\right)$

表13 咀嚼終末域（くしだんご）

\begin{tabular}{c|cccc}
\hline \hline & F.B. & L.O. & $0^{\circ}$ & M. $0^{\circ}$ \\
\hline 被験者 A & 0.52 & 0.30 & 0.72 & 0.38 \\
被験 者 B & 0.04 & 0.02 & 0.02 & 0.10 \\
被 験者 C & 0.04 & 0.14 & 0.13 & 0.06 \\
被 験 者 D & 0.55 & 0.45 & 0.25 & 0.36 \\
被験 者 E & 0.38 & 0.24 & 0.29 & 0.08 \\
\hline $\bar{X}$ & 0.31 & 0.23 & 0.28 & 0.20 \\
s.d. & 0.22 & 0.15 & 0.24 & 0.14 \\
\hline \multicolumn{4}{l}{} \\
\hline
\end{tabular}

ての咬合様式において咀嚼終末域は小さかった。また咬 合様式間における有意差は認められなかった（表 14）.

アーモンド咀嚼時では，F. B. : $0.51 \pm 0.32 \mathrm{~mm}^{2}$, L. O. : $0.46 \pm 0.36 \mathrm{~mm}^{2}, \quad 0^{\circ}: 0.49 \pm 0.37 \mathrm{~mm}^{2}, \quad$ M. $0^{\circ}: 0.36 \pm 0.21 \mathrm{~mm}^{2}$ であった。 $0^{\circ}$ の咀鲫終末域はF. B., L. O. と同程度であり, M. $0^{\circ}$ の平均咀礵終末域 が他の咬合様式より小さかったが，統計的に有意ではな かった（表 15）.

IV. 咀嚼能力と咀嚼終末域の関係

予備実験においてアーモンドと人工試料は，よく類似 した性状であることがわかった。 そこで，咀緭能力の結 果とアーモンド咀䚓時の咀嚼終末域の結果を比較した。

咀嚼能力の各被験者の平均値は, 被験者 $\mathrm{A}: 1.31 \pm$ $0.33 \mathrm{~kg} \cdot \mathrm{cm} / \mathrm{g}$, 被験者 B : $2.91 \pm 0.79 \mathrm{~kg} \cdot \mathrm{cm} / \mathrm{g}$, 被験者 C : $1.61 \pm 0.33 \mathrm{~kg} \cdot \mathrm{cm} / \mathrm{g}$, 被験者 D : $1.41 \pm$ $0.24 \mathrm{~kg} \cdot \mathrm{cm} / \mathrm{g}$, 被験者 $\mathrm{E}: 1.12 \pm 0.21 \mathrm{~kg} \cdot \mathrm{cm} / \mathrm{g}$ で あった。

アーモンド咀嚼時に扔ける咀嚼終末位域の各被験者の 平均值は, 被験者 $\mathrm{A}: 0.44 \pm 0.13 \mathrm{~mm}^{2}$, 被験者 B： $0.04 \pm 0.01 \mathrm{~mm}^{2}$, 被験者 $\mathrm{C}: 0.27 \pm 0.11 \mathrm{~mm}^{2}$, 被験者

表14 咀罚終末域（カステラ）

\begin{tabular}{c|cccc}
\hline \hline & F.B. & L.O. & $0^{\circ}$ & M. $0^{\circ}$ \\
\hline 被 験者 A & 0.19 & 0.22 & 0.26 & 0.23 \\
被 験者 B & 0.02 & 0.01 & 0.03 & 0.09 \\
被 験 者 C & 0.01 & 0.04 & 0.19 & 0.03 \\
被 験 者 D & 0.23 & 0.16 & 0.23 & 0.11 \\
被 験 者 E & 0.09 & 0.30 & 0.10 & 0.03 \\
\hline $\bar{X}$ & 0.11 & 0.15 & 0.16 & 0.10 \\
S.d. & 0.09 & 0.11 & 0.09 & 0.07 \\
\hline
\end{tabular}

表15＼cjkstart咀嚼終末域（アーモンド）

\begin{tabular}{|c|c|c|c|c|}
\hline & F.B. & L.O. & $0^{\circ}$ & M. $0^{\circ}$ \\
\hline 被験者 A & 0.53 & 0.51 & 0.48 & 0.22 \\
\hline 被験者 B & 0.02 & 0.05 & 0.04 & 0.05 \\
\hline 被験者 C & 0.41 & 0.16 & 0.17 & 0.35 \\
\hline 被験者 D & 1.03 & 0.52 & 0.65 & 0.57 \\
\hline 被 験 者 E & 0.54 & 1.07 & 1.09 & 0.60 \\
\hline $\bar{X}$ & 0.51 & 0.46 & 0.49 & 0.36 \\
\hline s.d. & 0.32 & 0.36 & 0.37 & 0.21 \\
\hline
\end{tabular}




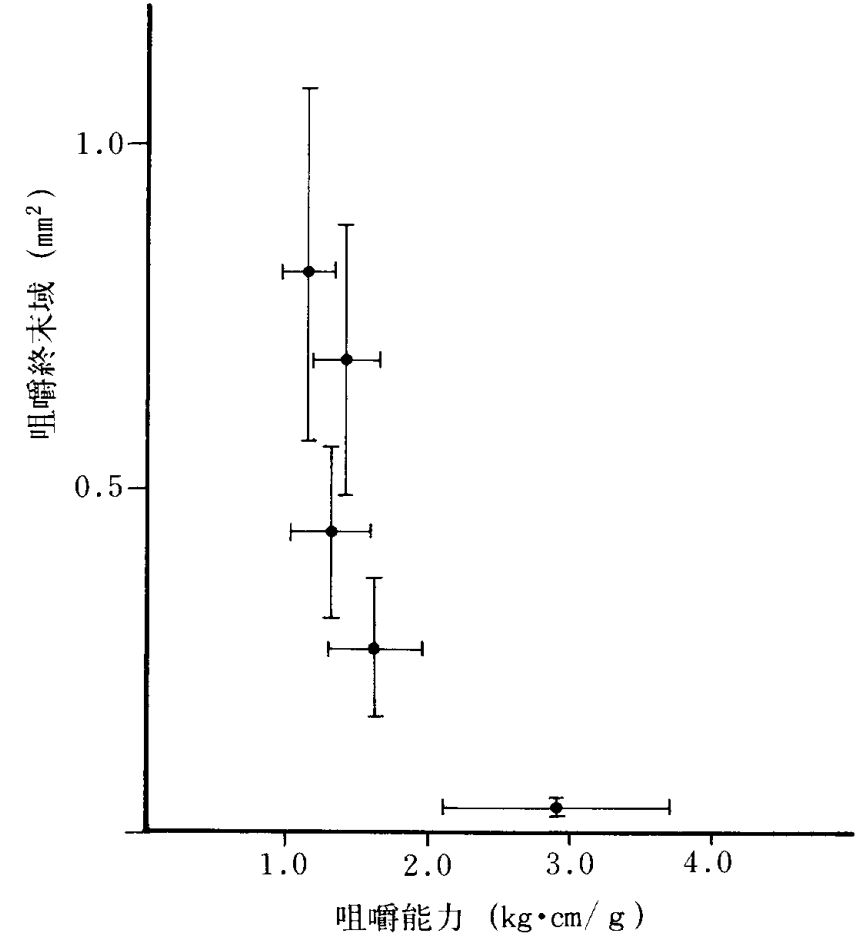

図 6 咀㘉能力と咀嚼終末域の関係

$\mathrm{D}: 0.69 \pm 0.20 \mathrm{~mm}^{2}$, 被験者 $\mathrm{E}: 0.83 \pm 0.26 \mathrm{~mm}^{2}$ で あった。

これらの值を, 横軸を咀賈能力, 縦軸を咀嚼終末域に とってプロットしたグラフを図6に示した。この結果よ り咀嚼能力の高いものは咀嚼終末域が小さく，咀嚼能力 の低いものは咀嚼終末域が大きい傾向があることがわ かった。

\section{考察}

\section{I . 研究方法}

A. 人工試料および食品の性状について

咀嚼運動記録に用いる食品を柳沢ら $(1985)^{17)}$ の報告 を参考にして選出した。柳沢らは食品を性状によって客 観的に分類するため，145品種の食品をテクスチュロ メータを用いて硬さ，弾力性，凝集性，付着性について 测定し，その特徵によって基本型，I 型， I 型，付着 型，スポンジ型，ゲル型の6種に分類している，本研究 では各型に分類される食品の中から比較的均一な性状で あり，入手が容易な食品として，ゆでた人参，焼肉，か まぼこ，くしだんご，カステラ，アーモンドを選び，テ クスチュロメータを用いてその性状を测定した。その結 果, これらの食品は柳沢らの報告とほぼ一致する性状で あることが確認できた。

さらに咀嚼能力試験の結果と咀嚼運動記録の結果を比
較するために，咀噮能力試験に用いる人工試料の性状を テクスチュロメータを用いて测定したところ硬さのみが 大きい性状であり，アーモンドに類似していることがわ かった。

\section{B. 実験用義歯について}

各種人工歯や咬合様式を変化させた場合の咀嚼機能へ の影響を検討するためには，数種の人工歯を排列した実 験用義歯が必要である，この種の奏験には，複数の義歯 を作製する方法 ${ }^{3)}$ ，複製義歯を作製して人工歯のみを変 える方法 ${ }^{26)}$, 義柬の床部分は共通にして人工歯部分を交

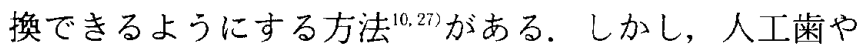
咬合様式別に義歯床を作製すると義歯床基底面や床研磨 面の形態，および咬合高径が変化する危険性がある。 そ こで,この危険性が最も少ない方法として四歯部人工歯 のみが交換できる実験用義歯を作製した。

本実験用義歯は，一下顎義歯の動摇による MKG 記録の 誤差を防ぐためにOPAアタッチメントを用いた ${ }^{283}$.

C. 咀嚼能力について

咀嚼能力の評価は, 一般的に篩分法が行われており, ピーナッッ，生米，にんじん，加まぼこなどを用いた方 法が報告されている

これらの自然食品には吸水性があるため，実験前後の 含水量や試料科量の際の乾燥の程度なよ゙が影響して，測 定値に誤差を生じる危険があり，操作も繁雑である。 そ こで本研究では佐藤 $(1958)^{16)}$ が開発した人工試料を用 いた。この人工試料はカルナウバ・ワックスと硫酸バリ ウムから成り, 吸水性のない均一な試料である.上田 $(1959)^{30)}$ は，この試料の人体咀嚼による粉砕粒子の分 布が Rosin-Rammlar の実験式, $y=\mathrm{e}^{-\mathrm{bx}} \mathrm{n}^{\mathrm{n}}$ （y：篩上量, $\mathrm{x}$ : 粒子径, $\mathrm{e}$ ：自然対数の底, $\mathrm{b}, \mathrm{n}$ : 粉砕機構によっ てきまる恒数）に近似し，篩上\%の 2 回対数老縦軸に， 篩径の 1 回対数を横軸にとったグラフ上で直線分布を示 すと述べている，さらに太田 $(1966)^{23}$ は，その直線の 傾斜である恒数 nがごく限られた範同でしか变動しな いことを実証したうえで，咀嚼による粉砕試料の8 mesh 穊上量と粉砕に要した仕事量の関係を明らかに し，単一篩による咀嚼能力の表示を可能にした。本研究 ではこの人工試料 $5 \mathrm{~g}$ を被験者に咀嚼させ， 8,14 , 28，48，100 meshの5 種の篩にかけて分離した。 その 粒度分布を前述のグラフ上にプロットしたところ，直線 性は完全ではなかったが，同一被験者の 8 mesh 篩上量 における咬合様式による篩上量の差は他の篩においても ほぼ同傾向であった。したがって 8 mesh 篩上量を太田 の式に代入して求めた値を各義歯使用時の咀嚼能力とす 
ることは妥当であると判断した。

D． 咀嚼運動記録について

1. 記録装置について

本研究では義歯の人工歯および咬合様式の変化が咀嚼 運動に及ぼす影響を調べることが目的であるので咀嚼運 動の記録はできるだけ生理的に自然な状態で行う必要が ある。この目的に合致した非接触型の顎運動記録装置に はマグネットを利用する方法 ${ }^{31}$, 22) と LED を用いる方法 ${ }^{33}$ があるが，LEDを用いる方法は 3 次元的な運動を同時 に記録，再生するためには比較的大規模な装置を必要と するため，本研究では小型のマグネットの動きをセン サーでとらえる MKGを用いた。

MKG の精度については数多く報告されているが34.35), そのほとんどが $\mathrm{K}$ - 5 型に関するすのである，本研究に 用いた K-6 型はセンサー・アレイが大幅に改良された ため $\mathrm{MKG}$ 特有のひずみが解消され，特に基点から離れ た位置での精度が向上している ${ }^{36}$.

K-6 型 MKG の精度について調べたところ，前後方 向で最大 $4.0 \%$ ，左右方向で最大 $6.3 \%$ であった。また分 解能は $0.05 \mathrm{~mm}$ であり, 本研究に十分な精度と分解能 を有していると判断した。

\section{2. 咀嚼リズムについて}

咀嚼周期の所要時間を求めるためには，連続した咀嚼 運動記録を 1 周期毎に分解しなければならない。その分 解の基準として咀嚼運動記録中の顎位が最初に記録した 咬頭嵌合位に戻る点で分解できることが望ましい，しか し，本研究の咀嚼運動記録では咀鲴中の顎位は必ずし屯 この咬頭嵌合位に復位するとは限らないことが観察され た。その原因として義歯の動摇，咬合面間の食品の介在 が考えられる．そこで，咬頭嵌合位に比較的近い位置で 運動方向が上方から下方に変化する点において咀礵運動 記録の分解を行った。咀㘉運動記録はデジタル・レコー

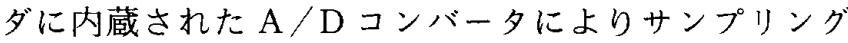
周期 $100 \mathrm{~Hz}$ で記録されているので，1 1 つの咀罚周期に 含まれるデー夕数をカウントすることによりその所要時 間を測定した. したがって本装置の測定誤差は土10 msec であり，本研究に十分な精度であると判断した。

\section{3. 咀嚼終末域について}

咀踾終末域を求めるためには咀嚼終末点の位置を測定 しなければならない，そこで，まず咀嚼運動における咀 嚼終末点をどの点にするかを決定した。咀嚼相について の研究は Zsigmondy (1912) ${ }^{37)}$ の 3 相説, Gysi (1926 )$^{38)}$ の 4 相説が知られており，これらの説では咀徱の各 相が明確に分かれている。しかし，咀罾運動は切れ目の
ない連続した運動であるので開始点と終末点を決定する のは困難である，本研究では咀嚼りズムに関する実験と 同様に，咬頭嵌合位に比較的近い位置で運動方向が上力 加ら下方へ変わる点を咀啷終末点とした。この点は Murphy (1965) ${ }^{39}$ の 6 相説における centric occlusion から preparatory phase に移行する点に相当する と考えられた。

II. 実験結果

A. 咀嚼能力について

本研究で用いた人工歯は，有咬頭人工歯である $\mathrm{F}$. B. , L. O. と無咬頭人工歯である $0^{\circ} ，$ M. $0^{\circ}$ に分類す ることができる．有咬頭人工歯之無咬頭人工歯，あるい は解剖学的人工歯之非解剖学的人工歯の咀嚼能力の優少 は, 古くから研究の対象となり，人工蒾の咀嚼能力に関 する多くの論文が発表されている．Thompson（1937 )$^{40)}$, Frechette (1955) ${ }^{41}$, 増田 (1974) ${ }^{15\rangle}$ らは, 非解 剖学的人工歯上り解剖学的人工歯の方が咀嚼能率が優れ ていたと報告している，これに対して Manly ら（1951 )$^{8)}$, 津留 $(1961)^{9)}$ は, 非解剖学的人工歯の方が咀嚼能 率が優れていると報告している．また，Sobolik（1938 )$^{26)}$, Bascom (1962) ${ }^{10)}$ らは両者の咀嚼能率に有意差 は認められないと述べている。ほとんどの研究で節分法 による咀嚼能力の評価を行っているにもかかわらず，研 究者により結果が異なり，共通の見解は得られていな い，その原因として，実験用義歯の構造の違い，試験食 品の種類の違い, 咀翾能力の表示法の違いが挙げられ る，特に，試験食品の性状は実験結果に大きく影響する 上考えられる. 過去の研究における試験食品は日常の食

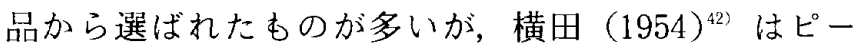
ナッツのように咀翾回数が多くなるにつれて $40 〜 50 \%$ が油として析出してしまうものや生米の上うに水分によ り性状が脆弱化するものは咀嚼能力試験の試料として問 題があると指摘している。このような日常食品に共通す

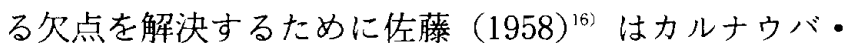
ワックスと硫酸バリウムから成る人工試料を開発した。 鯂見 $(1984)^{222}$ はこの人工試料を用いて総義歯装着者の 咀嚼能力を測定し，安定した再現性を実証している。こ れらの一連の研究から，この人工試料は咀嚼能力の測定 用試料之して優れた性状を有している之判断し，本研究 に用いた。まず，この試験人工試料がどのような日常食 品之類似した性状であるかを調べるために，テクスチュ ロメー夕を用いて数種の食品之比較を行ったところ, 凝 集性抢よび，弾力性は小さく，硬さのみが大きく，ア一 モンドに類似した性状であることがわかった。したがっ 
てこの試験試料を用いて咀嚼能力を測定することによ り，アーモンドのような硬さのみが大きい食品を咀嚼し たときの咀嚼能力を推察できると考えられる。

本研究における義歯装着者の勗嚼能力は, 最小 0.88 $\mathrm{kg} \cdot \mathrm{cm} / \mathrm{g}$, 最大 $4.01 \mathrm{~kg} \cdot \mathrm{cm} / \mathrm{g}$, 平均 $1.68 \pm 0.77$ $\mathrm{kg} \cdot \mathrm{cm} / \mathrm{g}$ であった。 中村 $(1982)^{43)}$ は同じ人工試料 を用いて健常有歯顎者の咀嚼能力を測定し, 平均 $4.5 \pm$ $0.6 \mathrm{~kg} \cdot \mathrm{cm} / \mathrm{g}$ と報告しておうり,この值と本研究の值を 比較すると健常有歯顎者に対する総義菌装着者の勗嚼能 力の回復率は 37\% であった. Manly ら $(1951)^{7}$, Yurkstas ら $(1964)^{12)}$, 増田 $(1974)^{15)}$ は試験食品に ピーナッッを用いて実験を行った結果, 総義歯による咀 嚼能力の回復率はそれぞれ $25 ， 12 ， 35 \%$ であったと報 告している. また，石原（1955） ${ }^{293}$ は生米を用いた実験 で約 $20 \%$ と報告している．これらの過去の研究は本研 究と試験食品が異なるため直接比較することは困難であ るが，本実験に用いた実験用義歯による咀嚼能力は増田 の値に近似しており；かなり良好な回復であったと考え られる。

つぎに義歯の咀嚼能力を咬合様式間で比較すると, F. B., L. O. の有咬頭人工歯より $0^{\circ}$ および $0^{\circ}$ の咬合 面に機能突起を与えて平衡咬合を可能にした M. $0^{\circ}$ の 万が咀嚼能力が高い傾向があった。本研究でこのような 結果を得た要因の一つに試験試料の性状が挙げられる. すなわち，この人工試料は硬さのみが大きく，脆い性質 であるため咬合面のフラットな人工歯による垂直的な力 で容易に破壊できたためと思われる．この結果から全て の食品に関する人工歯の優少を判定することは困難であ るが, 食品の性状によっては咬合面のフラットな人工歯 が有効に咀嚼能力を発揮できることが示唆された。

B. 咀嚼りズムについて

正常有㐘顎では, 開口筋之閉口筋が協調して, 一定の リズムで咀嚼運動が行われる。このような運動は歯根 膜, 顎関節や咀嚼筋の受容器によるフィード・バック機 構によって調節されているといわれている(4). 総義柬装 着者に関して, 辻井 $(1972)^{13 /}$ が患者の機能に調和した 義歯では咀嚼筋の活動がリズミカルになると報告してお り，このことは歯根膜が失われた総義歯装着者でも顎関 節や咀嚼筋の受容器が咀嚼りズムの安定性に寄与してい ることを示唆している.

そこで, 咬合様式が咀嚼リズムの安定性に及ぼす影響 について比較するため, 咀嚼運動記録から咀嚼開始直後 と與䓵下直前を除く最す安定した 10 ストロークを選出し, 咀嚼運動記録を各咀嚼周期に分解して個々の所要時間を
測定して, 咀嚼周期の所要時間の平均之標準偏差から変 動係数を求めた.

付着性の食品であり, 弾力性, 凝集性が大きいくしだ んご, 硬さは小さいが, 弾力性, 凝集性が大きい食品で あるカステラ, 硬さのみが大きい食品であるアーモンド の 3 種の試料では, 咬合様式が咀噮りズムに及ぼす影響 はほとんど認められなかった。

ゆでた人参，焼肉㧍よびかまぼこにおいては，F．B， L. O. に比較して， $0^{\circ}$ の咀鲫リズムが不規則になる傾 向があった：これらの咬合様式の相違は，F．Ｂ．および L. O. は有咬頭人工歯で平衡咬合が付与されているのに 対し， $0^{\circ}$ は無咬頭人工歯で平衡咬合が付与されていな い点である。すなわち，これらの食品においては咬頭の 有無之, 平衡咬合か非平衡啞合かが唨礵リズムに影響を 及ぼす因子であることになる。

一般に, 無咬頭人工歯で咬合平衡を与えるためにはト 顎臼歯後方部にバランシング・ランプが付与される。令 回, 上顎第一大臼歯近心部に機能突起を, またそれに対 合する下顎第一大臼歯部に窩を形成して平衡咬合が可能

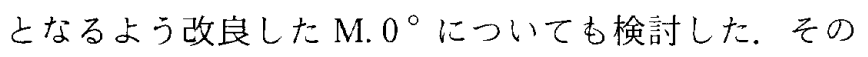
結果, M. $0^{\circ}$ は $0^{\circ}$ に比較して有意に咀嚼リズムが安定 し，F.B，およびL.O.に近似したものとなった。

$0^{\circ}$ 人工歯は, 咬頭斜面がないので, 機能時に側方告 を生じることがなく, 義歯の安定に有利である反面, 咬 頭嵌合位が明確でないので，咀嚼リズムを不安定にする 要因になることが指摘されている祽。本研究において 屯， $0^{\circ}$ 人工歯は咀㽆りズムを不安定にする可能性があ ることが明かになった。しかし， $0^{\circ}$ 人工㐘で平衡晈合 を可能にした M. $0^{\circ}$ では眼リズムが改善されたこと から，安定した咀嚼リズムを得るためには，平衡咬合を 付与する必要があることがわかった。

C. 咀嚼終末域について

義歯の維持安定あるいは咀䍛能率の観点では, 夕ッピ ング・ポイントや咀嚼終末位は 1 点に収束することが望 ましいが，実際には，ある程度のばらつきを有してい る. そこで, 本研究では, 咀嚼終末位のばらつきの程度 を客観的に比較するために咀嚼終末域を算出し, 咬合様 式間で比較を行った.

くしだんご，カステラおよびアーモンド咀嚼時には， 咬合様式間で有意差は認められなかった。

ゆでた人参咀嚼時の平均咀嚼終末域は統計的有意差は なかったが， $0^{\circ}$ が他の咬合様式より若干大きい值を示 L, F. B., L. O., M. $0^{\circ}$ はほぼ近似した值であった。 ゆでた人参のようなほとんど罍活動を必要としない食 
品では, 咀礵終末域は義歯自体の安定性に左右される可 能性がある，00で咀嚼終末位のばらつきがやや大き かったのは咀嚼中に咬頭嵌合位へ顎位を規制する機能を あたないことが原因であると思われる，咬合面に機能突 起を与えて両側性平衡咬合を可能にした M. $0^{\circ}$ は F. B., L. O. と同程度の咀嚼終末域であり, 機能突起の 有効性が示唆された。

焼肉は硬さ, 弾力性, 凝集性のすべてが大きいため, 大きな咀嚼活動を必要とする食品であり，このタイプの 食品を咀嚼するためには，広い側方運動域で滑走切断す ることが必要である，F. B., L. O.，0においては同 程度の比較的広い咀嚼終末域が観察された。.F. B. お上 びL.O. では，咬合の平衡が得られており，咬頭嵌合 位から少し離れた位置まで側方運動してお義歯の安定が 阻害される危険性は小さいであ万う。しかし，0゚では 柳田 $(1975)^{457}$ が無咬頭人工歯の欠点として挙げたよう に咀嚼終末域が広くなった。このことは義歯の安定性や 筋の協調性などの点で不利であると考えられる。

かまぼこはテクスチュロメー夕による測定において， 1 回目の破壊で完全に切断されるので凝集性が定量でき ない食品であった。しかも弾力性が大きいため，この夕 イプの食品は義歯の切断能が不足すると咀啷が困難な食 品であると考えられる，かまぼこ咀嚼時においては，F． B. の咀徱終末域加他の咬合様式と比較して小さく, こ の種の食品に対するF.B. の有効性が示唆された。

咀嚼リズムと咀嚼終末域に関する結果を総括すると, くしだんご，カステラ，アーモンド咀嚼時には咬合様式 が咀嚼りズムおよび咀嚼終末域に与える影響は小さかっ た。しかし，ゆでた人参，焼肉，かまぼこ咀嚼時では

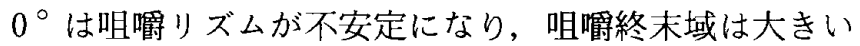
傾向があった，また，特に焼肉咀嚼時において平衡咬合 を付与した F. B., L. O. の咀礵終末域が $0^{\circ}$ と同程度 に大きかったにあかかわらず咀嚼りズムは $0^{\circ}$ と比較し て有意に安定していたことから平衡咬合の必要性が示唆 された.

機能突起を付与した M. $0^{\circ}$ は $0^{\circ}$ と比較して咀嚼り ズムは安定し, 咀嚼終末域は小さいことから M. $0^{\circ}$ に 付与した機能突起の有効性が示唆された。

D. 咀嚼能力之咀礵終末域の関係について

人工試料と日常の食品の性状を比較するために，人工 試料および数種の食品をテクスチュロメー夕を用いて測 定したところ人工試料はアーモンドと類似した性状であ ることがわかった，そこで咀嚼能力と咀鲅終末域の関係 を調べるために人工試料によって測定した咀嚼能力と
アーモンド咀嚼時の咀礵終末域に関して被験者每の平均 を算出し, 横軸を咀嚼能力 $(\mathrm{kg} \cdot \mathrm{cm} / \mathrm{g})$, 縦軸を咀嚼 終末域 $\left(\mathrm{mm}^{2}\right)$ にとったグラフにプロットした。 その

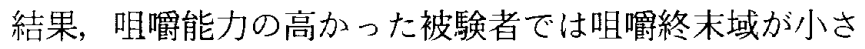
く, 咀嚼能力の低かった被験者では咀嚼終末域が大きい ことがわかった．また，咀㘉能力が中程度であったもの は咀嚼終末域む中程度であり，咀嚼終末域の小さい被験 者ほざ咀嚼能力が高く, 咀嚼終末域が大きい被験者ほど 咀啷能力が低い傾向があった（ $\mathrm{r}=-0.845 ）$ 。すなわち 咀嚼終末域が小さい被験者では咀鲅終末位が一点に集中 する傾向があり，そのため義歯が安定し，最大咬合接触 面積で咬合できるため高い咀䭅能力を発揮できたものと 考えられる。逆に咀賗終末域が大きかった被験者では咀 鲋終末位のばらつきが大きいため義歯が不安定になりや すく, 咬合接触面積む小さくなるため咀噮能力が低く なったものと考えられる。

\section{結論}

人工歯の種類および咬合様式が咀㘉能力に及ぼす影響 を調べる目的で， 4 種（F.B., L. O. , $0^{\circ}$, M. $0^{\circ}$ ) の 臼歯部人工歯が交換可能な実験用総義歯を作製し，5名 の被験者について，人工試料を用いた咀噮能力の測定， 6 種の食品（ゆでた人参，焼肉，かまぼこ，くしだん ご，カステラ，アーモンド）の咀嚼時における咀礵りズ ムの所要時間および咀礵終末域について検討した。 その 結果は以下のとおりである。

1. 実験用総義歯による咀翾能力は, 最小 $0.88 \mathrm{~kg} ・$ $\mathrm{cm} / \mathrm{g}$, 最大 $4.01 \mathrm{~kg} \cdot \mathrm{cm} / \mathrm{g}$, 平均 $1.68 \pm 0.77 \mathrm{~kg} \cdot$ $\mathrm{cm} / \mathrm{g}$ であった.

2. 無咬頭人工歯である $0^{\circ}$ は有咬頭人工歯である F. B. , L. O. より高い咀嚼能力を示した. $0^{\circ}$ の第一大 臼歯に機能突起を与えて平衡咬合を可能にした M. $0^{\circ}$ は $0^{\circ}$ と同程度の咀嚼能力であった。

3. 咀嚼周期の所要時間のばらつきを变動係数によっ て比較したところ， $0^{\circ}$ はF. B.， L. O. より咀嗰リズ ムが不安定になる傾向があった。また，M. $0^{\circ}$ はF. B. , L. O. と同程度であり， $0^{\circ}$ より咀嚼りズムが安定する 傾向があった。

4. 咀嚼終末位のばらつきの程度を咀嚼終末域によっ

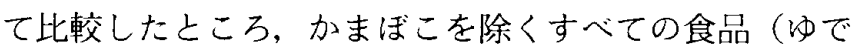
た人参，焼肉，〈しだんご，カステラ，アーモンド）に おいて M. $0^{\circ}$ の咀嚼終末域は他の咬合様式に比較して 小さかった。特に，凝集性の大きい焼肉咀嚼時におい て, M. $0^{\circ}$ の咀嚼終末域は他の咬合様式より有意に小さ 
かった。

5.人工試料と食品の性状をテクスチュロメータで測 定し比較したところ，人工試料はアーモンドと類似した 性状であることがわかった。そこで人工試料で測定した 咀嚼能力とアーモンド咀嚼時の咀嚼終末域を比較したと ころ, 咀嚼能力が大であった被験者は, 咀噮終末域が小 さく, 咀嚼能力が小であった被験者は, 咀鮁終末域が大 きい傾向があった。

稿を終わるにあたり，終始御想篤な御指導と御校閲を 賜った恩師豊田静夫教授に対し，心から感謝の意を表す るとともに，本研究に対して数多くの御教示をいただい た九州歯科大学坪根政治名誉教授，九州菌科大学生理学 教室中原敏教授, 九州歯科大学歯科補経学第 2 講座内田 康也教授に厚く御礼申し上げます。また，終始実験に御 協力をいただきました九州㐘科大学生理学教室中村修一 助教授, ならびに当教室三宅茂樹講師をはじめ補緅学教 室員諸兄，さらに，こころょく本研究の被験者を引き受 けて下さった諸氏に心より感謝いたします。

\section{引用文献}

1) Gysi, A. : Speciai teeth for cross-bite puposes. Dental Digest $33: 167-171,1927$.

2) Gysi, A. : Speciai teeth for cross-bite purposes. Dental Digest 33:670-677, 1927.

3 ) Sears, V. H. : Thirty years of nonanatomic teeth. J. Prosthet. Dent. $3: 596-617,1953$.

4) Hardy, I. R.: The development in the occlusal patterns of artificial teeth. J. Prosthet. Dent. $1: 14$ $-28,1951$.

5) Sosin, M. B.: Re-evaluation of posterior tooth forms for complete dentures. J. Prosthet. Dent. 11 : $55-61,1961$.

6) Levin, B. : A view of artficial posterior tooth forms including a preliminary report on new posterior tooth. J. Prosthet. Dent. $38: 3-15,1977$.

7) Manly, R. S. and Vinton, P. : A survey of the chewing ability of denture wearers. J. Dent. Res. $30: 314-321,1951$.

8) Manly, R. S. and Vinton, P.: Factors influencing denture function. J. Prosthet. Dent. $1: 578-586$, 1951.

9 ）津留宏道：義歯機能に関する生理的研究 II 咬合面形 態と義菌機能との関係。阪大菡学誌 $6: 353-366$, 1961.

10) Bascom, P. W. : Masticatory efficiency of complete dentures. J. Prosthet. Dent. 12:453-459, 1962.

11) Kapur, K. K. and Soman, S. D. : Masticatory performance and efficiency in denture wearers. J. Pro- sthet. Dent. 14, 687-694, 1964.

12) Yurkstas, A. A. and Emerson, W. H.: Decreased masticatory function in denture patients. J. Prosthet. Dent. 14:931-934, 1964.

13）辻井盈子：総義蒾装着者に打ける咀鲍様式の個人特性に 関する生理的観察. 口科誌 $21: 127-201,1972$.

14）增田信武：人工菊の咀嚼効率に関する研究 第 1 報 基 準值の算出について。補経誌 $17: 164-173,1973$.

15）増田信式：人工歯の咀稩効率に関する研究 第 2 報 咬 合面形態について。補経誌 $17: 401-421,1974$.

16）佐藤通泰：咀嚼能率の測定に使用する人工試料の研究. 九州歯会誌 $12: 440-457,1958$.

17）柳沢幸江，田村厚子，赤坂守人，寺元芳子：食品の物性 之摂食機能に関する研究 第 1 報 食品物性の器機的測 定, 並びに食品分類について。歯誌 $23: 962-983$, 1985.

18）西浦 恂, 権田悦通, 桑島 悧, 松本光彦: 複製義歯 (Duplicating denture) について。補経臨床 12 ： $296-304,1979$.

19）坪根政治, 豊田静夫, 三宅茂樹, 清水稔弘：Crosmer $20^{\circ}$ 日雬による第一大臼䨑を中心とした排列法。歯界展 望 $63: 1279-1284,1984$.

20) Pound, E. and Murrell, G. A. : An introduction to denture smplification Phase I. J. Prosthet. Dent. $26: 570-580.1971$.

21) Pound, E. and Murrell, G. A. : An introduction to denture simplification Phase П. J. Prosthet. Dent. $29: 598-607.1973$.

22）鱒見進一：軟性裏装材のレオロジカルな性質と咀謝能力 に及ぼす影響. 九州雨会誌 $38: 864-879,1984$.

23）太田俊平：エネルギーによる咀礵能力の表示法. 九州蒾 会誌 $20: 69-48,1966$.

24）城戸寛史，三宅茂樹，鱒見進一，小田耕平，城戸 修， 豊田静夫：MKG 記録時における頭部固定の必要性につ いて. 九州㐘会誌 $44: 381-385,1990$.

25）和久田一成：タッピング運動を利用した咬合採得法に関 する研究。九州菌会誌 $38: 880-901,1984$.

26) Sobolik, C. F. : Observation on occlusal forms by an edentulous dentist. Dent. Items. Interest. $60: 762$ $-771,1938$.

27) Trapozzano, V. R.: Tests of balanced and nonbalanced occlusions. J. Prosthet. Dent. $10: 476-487$, 1960.

28）羽田 勝, 高津佳彦, 河野文昭, 市川哲雄, 市場裕康, 今井守夫, 松本直之: 全部床義歯の動摇について 第 1 報 MKG 用いた测定分析法の検討。補緅誌 29 ： $1019-1027,1985$.

29）石原寿郎：篩分法による咀嗄能率の研究. 口病誌 22 : $207-255,1955$.

30）上田太郎：正常咬合者に扮ける咀嚼能率の研究。九州歯 会誌 $12: 562-582,1959$.

31) Jankelson, B., Swain, C. W., Crane, P. F. and Radke, J. C.: Kinesiometric instrumentation: a 
new technology. J. Amer. Dent. Assoc. 90:834$840,1975$.

32）端森崇弘, 桑原俊也, 中村康弘, 桑原隆男, 西尾公一, 宫内修平，丸山剛郎：咀嚼運動の恒常性に関する臨床的 研究. 補緅誌 $29: 647-656,1985$.

33）柴田孝典：下顎前突症における顎運動機能に関する研 究. 歯科学報 $81: 241-265,1981$.

34）三谷春保, 山下 敦, 井上 宏: Mandibular Kines iograph の原理とその忠実性について。補緅誌 21 ： $254-264,1977$.

35）并上: 宏, 西浦 恂, 山下 敦: MKG Analyzer の補 正効果. 補経誌 $27: 32-39,1983$.

36) Morikawa, M., Sako, M., Kido, H., Toyoda, S. and Kozono, Y.: Analysis tooth movement utilizing Mandibular Kinesiograph (MKG) Part 1 Chracteristic aspects and correction of MKG records, Dent. Mater. J. $7: 188-196,1988$.

37) Zsigmondy, O.: Über die Bewegungen des Unterkiefers beim Kauakt. Österr. Z. f. Stomat. 10 : $175-184,1912$.

38) Gysi, A. : Artikulation, Handbuch der Zahnheilk- unde, Bd. 3, Bluhm, München, 1926, $167-316$.

39) Murphy, T. R. : The timing and mechanism of the human masticatory stroke. Arch. Oral Biol. 10:981 $-994,1965$.

40) Thompson, M. J. : Masticatory efficiency as related to cusp form in denture prosthesis. J. Amer. Dent. Assoc. 24:207-219, 1937.

41) Frechette, A. R. : Masticatory forces associated with the use of various types of artificial teeth. J. Prosthet. Dent. 5 : 252-267, 1955.

42）横田成三：咀嚼機能の模型化による咀嚼粉砕の基礎奏 験. 九州㐘会誌 $8: 1-12,1954$.

43）中村修一：燕下の䦨について. 九州菡会誌 $36: 476-$ 482, 1982.

44）田島直孝：咀嚼運動に関する運動学的および筋電図学的 検討 II-1. 咀嚼運動相リズムおよび筋放電持続時間 について。補緅誌 $29: 355-371 ， 1985$.

45）柳田尚三：無咬頭人工蒾の排列一その理論と実際一 (1). 日本歯科評論 $393: 17-29,1975$. 